\title{
Structure of the deep demersal fish fauna off Newfoundland
}

\author{
P. V. R. Snelgrove* \& R. L. Haedrich \\ Newfoundland Institute for Cold Ocean Science, Memorial University of Newioundland, St. John's, \\ Newfoundland A1B 3X7, Canada
}

\begin{abstract}
Bottom trawls on the Newfoundland continental slope at depths from 204 to $2325 \mathrm{~m}$ near Carson Submarine Canyon $\left(45^{\circ} 30^{\prime} \mathrm{N}, 48^{\circ} 40^{\prime} \mathrm{W}\right)$ took 4222 individuals in 39 species of demersal fishes. The fauna was not strictly zoned, but showed a fairly uniform addition of species with increasing depth over the entire range. Lack of zonation may be related to the high production of the area, and its absence here casts doubt on the idea that faunal regions continuously rim the ocean basins. Dominant species were mainly macrourids (Macrourus berglax, Coryphaenoides rupestris, Nezumia bairdii, Nematonurus armatus) and the morid Antimora rostrata. Overall abundance, biomass, and diversity were least at the greatest depths. Only A. rostrata and C. rupestris were bigger-deeper; juveniles of both are abundant in shallow northern waters. The proportion of species belonging to shallow-water groups decreases steadily with depth, a pattern also seen in other data and implying ongoing invasion of the deep sea by fishes from the continental shelves
\end{abstract}

\section{INTRODUCTION}

The deep demersal fish fauna has been examined both south (Haedrich et al. 1975) and north (Haedrich \& Krefft 1978) of Newfoundland's continental slope. The work off New England found a clear pattern of zonation with depth, whereas the one farther north off Iceland found a mosaic where depth and temperature co-described the distribution patterns. The present study, in an area between these 2 regions, seeks to determine whether the Newfoundland fish fauna is intermediate in composition and relative abundance, and what sort of zonation patterns may be present. Vertical zonation in the distribution of benthic organisms is well documented (e.g. Day \& Pearcy 1968, Menzies et al. 1973, Haedrich et al. 1980, Pearcy et al. 1982, Carney et al. 1983), but it is not a ubiquitous feature of the ocean bottom. Merrett \& Marshall (1980) found no zonation in fishes on the Northwest African slope. They attributed this absence to the high productivity of the area, arguing that increased food availability broke down the zones that might otherwise have been expected. Because the Newfoundland region is

- Present address: Institute of Oceanography, McGill University, Montreal, Quebec H3A 2B2, Canada one of high primary production, it might be expected that zonation could be weak or absent.

We have approached the question with data from a 3 yr study conducted in the Carson Canyon region on the eastern edge of the Grand Bank of Newfoundland $\left(45^{\circ} 30^{\prime} \mathrm{N}, 48^{\circ} 40^{\prime} \mathrm{W}\right.$, Fig. 1). Sampling by the $\mathrm{M} / \mathrm{V}$

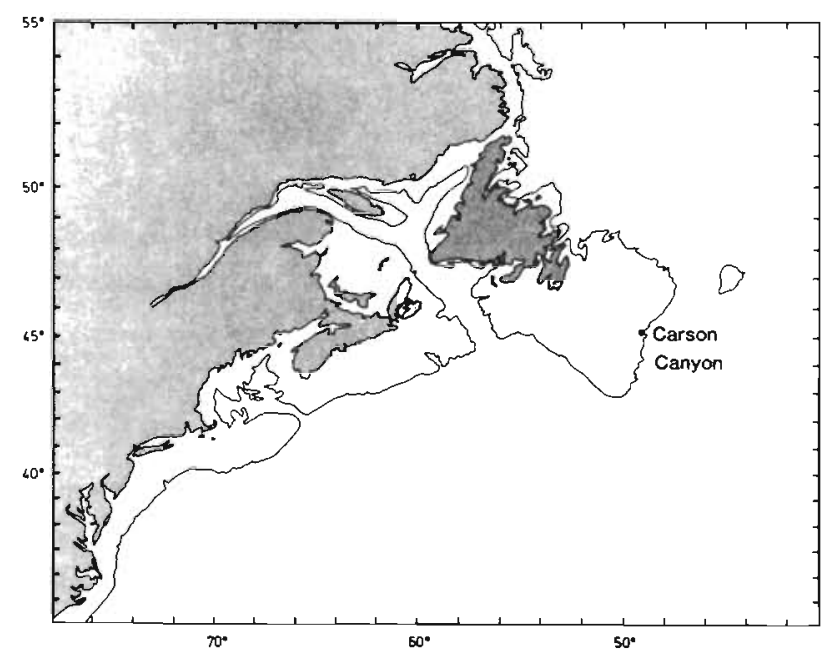

Fig. 1. Location of study area in the region of Carson Submarine Canyon on the eastern edge of the Grand Banks of Newfoundland, northwest Atlantic Ocean. Isobath follows the $200 \mathrm{~m}$ depth contour 
'Gadus Atlantica' was undertaken in June 1980 and May 1981 and by the R/V 'Oceanus' in September 1982. There were 32 successful deep benthic tows encompassing a depth range of 204 to $2325 \mathrm{~m}$. The data obtained from these trawls have been used to describe the faunal composition and vertical distribution of the fishes there, and to evaluate the results in the light of other similar studies.

\section{MATERIALS AND METHODS}

Station data associated with the samples are given in Table 1. An objective of the 'Oceanus' cruise was to obtain material for physiological studies (e.g. Graham et. al. 1985); trawling times on this cruise tended to be short and depths deep, and thus the number of species and specimens per individual trawl appears smaller than in those from the 'Gadus' cruises. Positions of the stations are plotted on the chart of Fig. 2. Representative material from the study has been deposited in the Newfoundland Museum, St. John's and the National Museum of Natural History, Ottawa.

The gear and sampling protocol are the same as that used in a similar program in the New York Bight (Haedrich et al. 1980). A $12.5 \mathrm{~m}$ Gulf-of-Mexico shrimp trawl (Marinovich Company) of $3.7 \mathrm{~cm}$ stretch mesh with a $2.5 \mathrm{~cm}$ heavy knotted liner in the cod end was used. Steel V-doors measuring $80 \times 120 \mathrm{~cm}$ were attached to $20 \mathrm{~m}$ bridles. The head rope was buoyed with a $30 \mathrm{~cm}$ diameter glass float (Benthos Company), and light chain was lashed at intervals along the footrope. The effective opening of this net is about $8 \mathrm{~m}$ (Bullis \& Cummins 1963) and an estimated bottom area of $2.2 \times 10^{4} \mathrm{~m}^{2}$ can be swept in an hour by a ship moving at $1.5 \mathrm{kn}$. Sampling time included only the time after the winch had stopped paying out and

Table 1. Station data associated with bottom trawl collections made on the continental slope off Newfoundland

\begin{tabular}{|c|c|c|c|c|c|c|c|c|c|c|}
\hline Station & Ship & Cruise & Latitude & Longitude & Date & $\begin{array}{l}\text { Mean } \\
\text { bottom } \\
\text { depth } \\
\text { (m) }\end{array}$ & Time & $\begin{array}{l}\text { No. of } \\
\text { species }\end{array}$ & $\begin{array}{l}\text { No. of } \\
\text { speci- } \\
\text { mens }\end{array}$ & $\begin{array}{c}\text { Weight } \\
(\mathrm{kg})\end{array}$ \\
\hline 816 & 'Gadus' & 37 & $45^{\circ} 23^{\prime} \mathrm{N}$ & $48^{\circ} 29^{\prime} \mathrm{W}$ & 3 Jun 80 & 900 & $1231-1250$ & 13 & 158 & 25.9 \\
\hline 838 & 'Gadus' & 37 & $45^{\circ} 18^{\prime} \mathrm{N}$ & $48^{\circ} 36^{\prime} \mathrm{W}$ & 4 Jun 80 & 1425 & $0812-0832$ & 12 & 246 & 28.4 \\
\hline 839 & 'Gadus' & 37 & $45^{\circ} 18^{\prime} \mathrm{N}$ & $48^{\circ} 36^{\prime} \mathrm{W}$ & 5 Jun 80 & 1200 & $1140-1220$ & 10 & 58 & 13.8 \\
\hline 853 & 'Gadus' & 37 & $45^{\circ} 18^{\prime} \mathrm{N}$ & $48^{\circ} 33^{\prime} \mathrm{W}$ & 5 Jun 80 & 1280 & $1410-1430$ & 10 & 64 & 18.4 \\
\hline 865 & 'Gadus' & 37 & $45^{\circ} 25^{\prime} \mathrm{N}$ & $48^{\circ} 36^{\prime} \mathrm{W}$ & 8 Jun 80 & 1050 & $0110-0130$ & 7 & 1566 & 132.8 \\
\hline 951 & 'Gadus' & 51 & $45^{\circ} 28^{\prime} \mathrm{N}$ & $48^{\circ} 30^{\prime} \mathrm{W}$ & 15 May 81 & 601 & $1402-1422$ & 12 & 181 & 27.4 \\
\hline 952 & 'Gadus' & 51 & $45^{\circ} 27^{\prime} \mathrm{N}$ & $48^{\circ} 28^{\prime} \mathrm{W}$ & 15 May 81 & 754 & $1700-1720$ & 10 & 388 & 85.3 \\
\hline 955 & 'Gadus' & 51 & $45^{\circ} 31^{\prime} \mathrm{N}$ & $48^{\circ} 29^{\prime} \mathrm{W}$ & 15 May 81 & 204 & $2030-2050$ & 5 & 18 & 70.0 \\
\hline 957 & 'Gadus' & 51 & $45^{\circ} 30^{\prime} \mathrm{N}$ & $48^{\circ} 29^{\prime} \mathrm{W}$ & 15 May 81 & 305 & $2245-2305$ & 5 & 72 & 40.2 \\
\hline 958 & 'Gadus' & 51 & $45^{\circ} 29^{\prime} \mathrm{N}$ & $48^{\circ} 29^{\prime} \mathrm{W}$ & 16 May 81 & 412 & $0000-0020$ & 2 & 2 & 0.9 \\
\hline 959 & 'Gadus' & 51 & $45^{\circ} 31^{\prime} \mathrm{N}$ & $48^{\circ} 22^{\prime} \mathrm{W}$ & 16 May 81 & 809 & $0820-0840$ & 11 & 161 & 35.1 \\
\hline 960 & 'Gadus' & 51 & $45^{\circ} 31^{\prime} \mathrm{N}$ & $48^{\circ} 25^{\prime} \mathrm{W}$ & 16 May 81 & 499 & $1053-1117$ & 8 & 159 & 14.7 \\
\hline 961 & 'Gadus' & 51 & $45^{\circ} 33^{\prime} \mathrm{N}$ & $48^{\circ} 23^{\prime} \mathrm{W}$ & 16 May 81 & 405 & $1225-1245$ & 10 & 48 & 14.3 \\
\hline 962 & 'Gadus' & 51 & $45^{\circ} 33^{\prime} \mathrm{N}$ & $48^{\circ} 10^{\prime} \mathrm{W}$ & 16 May 81 & 1305 & $1410-1430$ & 11 & 146 & 47.8 \\
\hline 964 & 'Gadus' & 51 & $45^{\circ} 36^{\prime} \mathrm{N}$ & $47^{\circ} 56^{\prime} \mathrm{W}$ & 16 May 81 & 1475 & $1920-1940$ & 4 & 8 & 3.4 \\
\hline 1350 & 'Oceanus' & 126 & $45^{\circ} 29^{\prime} \mathrm{N}$ & $48^{\circ} 31^{\prime} \mathrm{W}$ & 11 Sep 82 & 283 & $1205-1235$ & 7 & 111 & 63.5 \\
\hline 1352 & 'Oceanus' & 126 & $45^{\circ} 18^{\prime} \mathrm{N}$ & $48^{\circ} 35^{\prime} \mathrm{W}$ & 11 Sep 82 & 1350 & $1730-1800$ & 8 & 147 & 46.0 \\
\hline 1354 & Oceanus' & 126 & $45^{\circ} 21^{\prime} \mathrm{N}$ & $47^{\circ} 43^{\prime} \mathrm{W}$ & 12 Sep 82 & 2325 & $0635-0710$ & 4 & $3 \hat{i}$ & 16.1 \\
\hline 1356 & 'Oceanus' & 126 & $45^{\circ} 18^{\prime} \mathrm{N}$ & $47^{\circ} 51^{\prime} W$ & 12 Sep 82 & 2215 & $1545-1615$ & 7 & 33 & 9.4 \\
\hline 1357 & 'Oceanus' & 126 & $45^{\circ} 24^{\prime} \mathrm{N}$ & $47^{\circ} 46^{\prime} \mathrm{W}$ & 13 Sep 82 & 1985 & $0600-0635$ & 4 & 18 & 9.6 \\
\hline 1359 & 'Oceanus' & 126 & $45^{\circ} 33^{\prime} \mathrm{N}$ & $47^{\circ} 36^{\prime} \mathrm{W}$ & 13 Sep 82 & 1710 & $1325-1345$ & 5 & 16 & 6.2 \\
\hline 1360 & 'Oceanus' & 126 & $45^{\circ} 33^{\prime} \mathrm{N}$ & $47^{\circ} 30^{\prime} \mathrm{W}$ & 13 Sep 82 & 1863 & $1605-1630$ & 3 & 18 & 10.8 \\
\hline 1361 & 'Oceanus' & 126 & $45^{\circ} 41^{\prime} \mathrm{N}$ & $47^{\circ} 37^{\prime} \mathrm{W}$ & 13 Sep 82 & 1360 & 1955-2015 & 6 & 27 & 7.9 \\
\hline 1363 & 'Oceanus' & 126 & $45^{\circ} 17^{\prime} \mathrm{N}$ & $48^{\circ} 34^{\prime} \mathrm{W}$ & 14 Sep 82 & 1205 & $1015-1035$ & 10 & 92 & 31.8 \\
\hline 1365 & 'Oceanus' & 126 & $45^{\circ} 08^{\prime} \mathrm{N}$ & $48^{\circ} 45^{\prime} \mathrm{W}$ & 14 Sep 82 & 1045 & $1555-1615$ & 5 & 15 & 2.9 \\
\hline 1366 & 'Oceanus' & 126 & $45^{\circ} 20^{\prime} \mathrm{N}$ & $48^{\circ} 34^{\prime} \mathrm{W}$ & 14 Sep 82 & 1175 & $1953-2013$ & 6 & 191 & 25.0 \\
\hline 1367 & 'Oceanus' & 126 & $45^{\circ} 19^{\prime} \mathrm{N}$ & $48^{\circ} 37^{\prime} \mathrm{W}$ & $15 \operatorname{Sep} 82$ & 1250 & $0730-0750$ & 9 & 87 & 43.1 \\
\hline 1368 & 'Oceanus' & 126 & $45^{\circ} 10^{\prime} \mathrm{N}$ & $48^{\circ} 33^{\prime} \mathrm{W}$ & 15 Sep 82 & 1343 & $1135-1155$ & 4 & 26 & 8.3 \\
\hline 1370 & 'Oceanus' & 126 & $45^{\circ} 18^{\prime} \mathrm{N}$ & $48^{\circ} 32^{\prime} \mathrm{W}$ & $15 \operatorname{Sep} 82$ & 1438 & $2030-2045$ & 3 & 9 & 4.8 \\
\hline 1372 & 'Oceanus' & 126 & $45^{\circ} 17^{\prime} \mathrm{N}$ & $48^{\circ} 34^{\prime} W$ & 16 Sep 82 & 1118 & $0645-0700$ & 5 & 85 & 30.0 \\
\hline 1373 & 'Oceanus' & 126 & $45^{\circ} 17^{\prime} \mathrm{N}$ & $48^{\circ} 26^{\prime} W$ & 16 Sep 82 & 1713 & 0955-1010 & 3 & 4 & 0.3 \\
\hline 1376 & 'Oceanus' & 126 & $45^{\circ} 19^{\prime} \mathrm{N}$ & $48^{\circ} 34^{\prime} \mathrm{W}$ & 16 Sep 82 & 1090 & $2105-2130$ & 5 & 45 & 17.8 \\
\hline
\end{tabular}




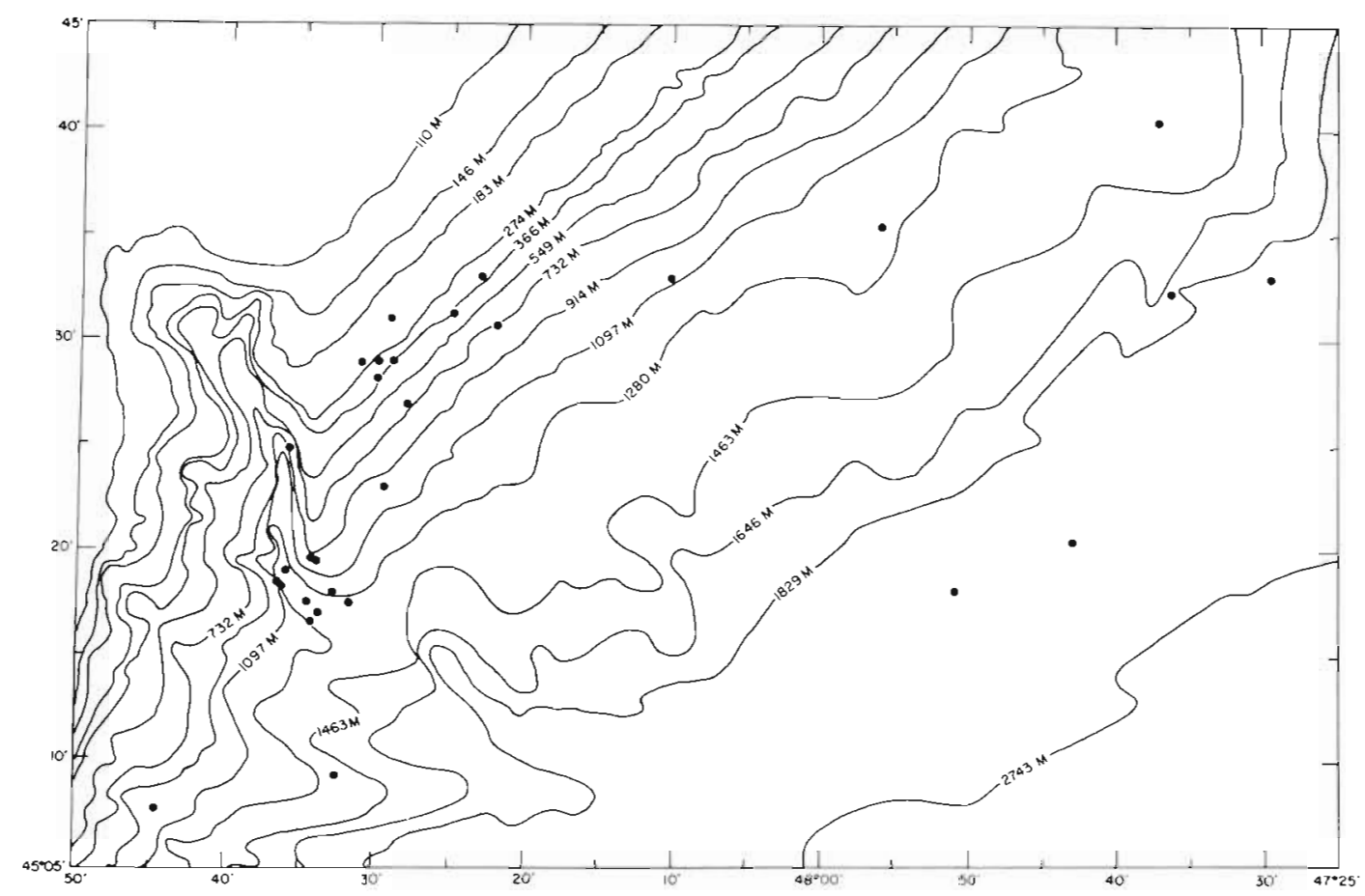

Fig. 2. Chart showing location of successful bottom trawl stations in the Carson Canyon region. Soundings in meters

before retrieval was begun. The speed of the ship during sampling was about $1.5 \mathrm{kn}$, so the average 20 min trawl swept an area of about $7.4 \times 10^{3} \mathrm{~m}^{2}$.

The material collected was either measured immediately and discarded (but only in the case of the more numerous and easily identified species), or fixed in $10 \%$ buffered formalin. The fixed material was later transferred to alcohol for identification, counting, and weighing in the laboratory. Single specimens of $\mathrm{Hy}_{Y}$ drolagus affinis and Harriotta raleighana were taken at Station 1363 (depth $1205 \mathrm{~m}$ ) but were not weighed or preserved because of their great size. They are included in the chi-square analysis and depth range profiles but excluded from all other analyses. Lycodonus mirabilis was caught at Station 951 (depth $601 \mathrm{~m}$ ) but was not kept or weighed. Length-weight regressions based on preserved specimens were used to estimate the biomass of those fishes discarded at sea.

The problems associated with net samples are well known. Cohen \& Pawson (1977) observed net avoidance by Synaphobranchus kaupi and Haedrich et al. (1975) were able to conclude, through comparison with observations from submersibles, that trawling consistently underestimates absolute abundance. Ohta (1983) has recently considered this problem in considerable detail. Problems in keeping the net fully open may have been an important factor in some samples, and large tears in the net also reduced the number of stations that could be used. Bottom terrain also influenced sampling. Rolling hills between $400 \mathrm{~m}$ and $600 \mathrm{~m}$ may have contributed to ineffective sampling. There were no stations completed between 2000 $\mathrm{m}$ and $2200 \mathrm{~m}$. This portion of the lower slope was particularly rough, and several nets were lost attempting to trawl.

To establish whether zonation was present, a variation of the chi-square test was employed. This method (Gardiner \& Haedrich 1978) tests the distribution across the area of upslope (i.e. deeper to shallower) and downslope (i.e. shallower to deeper) species boundaries using the formula:

$$
\chi^{2}=(\mathrm{Q} / \mathrm{K}) \times\left(\mathrm{V}-\left[\mathrm{K}^{2} / \mathrm{Q}\right]\right)
$$

where $Q=$ number of regions into which the area is arbitrarily divided; $\mathrm{K}=$ total number of species; $\mathrm{V}=$ sum of squares of boundaries (upslope or downslope) occurring in each region. The values calculated for the chi-square are compared to values in a chi-square table with degrees of freedom equal to $Q-1$. If the calculated value exceeds the value obtained from the table, the boundaries are distributed non-randomly, i.e. they are zoned. For details of the method, the original reference (Gardiner \& Haedrich 1978) should be consulted.

The chi-square test is quite applicable to this type of data according to an overview presented by Carney et al. (1983). A potential pitfall lies in the importance of the limits of each species as established by the sampling. Inconsistent sampling effort over the depth range can obscure zonation, particularly if an extremely wide 
range is sampled. Our sampling range, however, was not too extreme, and effort was directed as widely as the topography of the slope would permit.

Percentage similarity, PS, a commonly-used measure of faunal overlap, was calculated according to the formula of Whittaker \& Fairbanks (1958):

$$
\text { PS }=100 \Sigma \min \left(\mathrm{p}_{1 \mathrm{a}}, \mathrm{p}_{1 \mathrm{~b}}\right)
$$

where $\mathrm{p}_{\mathrm{ia}}=$ the proportion assumed by species $\mathrm{i}$ in sample $a_{i} p_{b}=$ the proportion assumed by species $i$ in sample b. Diversity, $H$, was calculated using the information function (Shannon \& Weaver 1963):

$$
\mathrm{H}=-\Sigma \mathrm{p}_{1} \ln \mathrm{p}_{1}
$$

where $p_{\mathrm{s}}=$ the fraction of the total comprised by species $i$ in a region. Evenness, J, was calculated according to:

$$
\mathrm{J}=\mathrm{H} / \mathrm{H}_{\max }
$$

where $H_{\max }=N \times \operatorname{abs} \mid 1 / N \ln 1 / \mathrm{Nl}$.

Regressions were performed on individual species and on all taxa combined to establish whether a correlation between size and depth of occurrence existed. The SAS statistical package (Ray 1982) was particularly useful for standard statistical procedures.

\section{RESULTS}

A complete list of species taken is given in Table 2 . The chi-square test was run on all stations, grouped

\begin{tabular}{|c|c|c|c|c|}
\hline & $\begin{array}{l}\text { No. of } \\
\text { stations }\end{array}$ & $\begin{array}{c}\text { No. of } \\
\text { specimens }\end{array}$ & Weight (kg) & Depth range $(\mathrm{m})$ \\
\hline Alepocephalus sp. Risso 1820 & 7 & 15 & 34.86 & $1118-2325$ \\
\hline Anarhichas lupus Linnaeus 1758 & 2 & 2 & 39.00 & $307-405$ \\
\hline Antimora rostrata Gunther 1878 & 26 & 402 & 147.02 & $499-2325$ \\
\hline Aspidophoroides monopterygius (Bloch) 1786 & 1 & 1 & 0.001 & 283 \\
\hline Careproctus reinhardti Kroyer 1862 & 1 & 2 & 0.002 & 900 \\
\hline Centroscyllium fabricii (Reinhardt) 1825 & 6 & 16 & 21.32 & $900-1350$ \\
\hline Chalinura brevibarbis Goode \& Bean 1896 & 1 & 12 & 3.37 & 2215 \\
\hline Coryphaenoides rupestris Gunnerus 1765 & 20 & 2429 & 223.78 & $405-1712$ \\
\hline Cottunculus microps Collett 1875 & 9 & 20 & 2.45 & $499-1475$ \\
\hline Gadus morhua Linnaeus 1758 & 3 & 17 & 6.98 & $204-307$ \\
\hline Gaidropsarus ensis (Reinhardt) 1838 & 7 & 10 & 1.34 & $405-1425$ \\
\hline Glyptocephalus cynoglossus (Linnaeus) 1758 & 5 & 11 & 3.78 & $405-1200$ \\
\hline Halosauropsis macrochir (Gunther) 1878 & 1 & 1 & 0.06 & 2215 \\
\hline Harriotta raleighana Goode \& Bean 1895 & 2 & 2 & 0.03 & $1205-2215$ \\
\hline HippogIossoides platessoides (Fabricius) 1780 & 1 & 3 & 0.03 & 204 \\
\hline Hydrolagus affinis (Capello) 1867 & 2 & 3 & 0.63 & $1205-2215$ \\
\hline Lionurus carapinus (Goode \& Bean) 1883 & 5 & 12 & 0.69 & $1710-2325$ \\
\hline Lycenchelys sarsi (Collett) 1871 & 2 & 4 & 0.23 & $499-601$ \\
\hline Lycodes atlanticus Jensen 1904 & 2 & 5 & 2.15 & $1305-1360$ \\
\hline Lycodes esmarki Collett 1875 & 4 & 21 & 17.92 & $283-809$ \\
\hline Lycodes perspicillus Kroyer 1845 & 1 & 1 & 0.11 & 283 \\
\hline Lycodes vahli Reinhardt 1831 & 3 & 5 & 2.25 & $405-809$ \\
\hline Lycodonus mirabilis Goode \& Bean 1883 & 6 & 29 & 0.51 & $601-1425$ \\
\hline Macdonaldia rostrata (Collett) 1889 & 3 & 4 & 0.60 & $1250-1475$ \\
\hline Macrourus berglax Lacepede 1801 & 24 & 585 & 181.20 & $204-1438$ \\
\hline Nematonurus armatus (Hector) 1875 & 4 & 15 & 3.20 & $1710-2325$ \\
\hline Nezumia bairdii (Goode \& Bean) 1877 & 15 & 218 & 30.18 & $405-1475$ \\
\hline Notacanthus chemnitzii Bloch 1788 & 2 & 12 & 0.78 & $1200-1425$ \\
\hline Phycis chesteri Goode \& Bean 1878 & 2 & 4 & 1.66 & $601-754$ \\
\hline Raja jenseni Bigelow \& Schroeder 1950 & 2 & 4 & 3.82 & $1205-1360$ \\
\hline Raja radiata Donovan 1808 & 7 & 21 & 90.54 & $204-1305$ \\
\hline Raja senta Garman 1885 & 2 & 2 & 0.91 & $809-900$ \\
\hline Reinhardtius hippoglossoides (Walbaum) 1792 & 9 & 25 & 54.95 & $754-1425$ \\
\hline Scophthalmus aquosus (Mitchill) 1815 & 2 & 4 & 4.35 & $809-1305$ \\
\hline Sebastes sp. & 8 & 169 & 32.01 & $283-1050$ \\
\hline Synaphobranchus kaupi Johnson 1862 & 23 & 141 & 17.81 & $405-1863$ \\
\hline Trachyrhynchus murrayi Gunther 1887 & 1 & 1 & 0.44 & 900 \\
\hline Triglops murrayi Gunther 1887 & 1 & 2 & 0.01 & 204 \\
\hline Zoarcid & 3 & 4 & 1.96 & $1200-1425$ \\
\hline
\end{tabular}

Table 2. Alphabetical list of species, catch statistics, and depth range over which each species occurred for fishes taken on the Newfoundland Continental Slope 
into regions of $200 \mathrm{~m}$ depth increase. Values of chisquare exceeded the lowest acceptable significance level of 0.05 ( $\mathrm{df}=8$ ) but not a level of 0.01 . This indicates that the distribution is zoned, but weakly, between 200 and $2300 \mathrm{~m}$.

The species recruitment curves along the depth gradient are shown in Fig. 3; the upper curve is for first

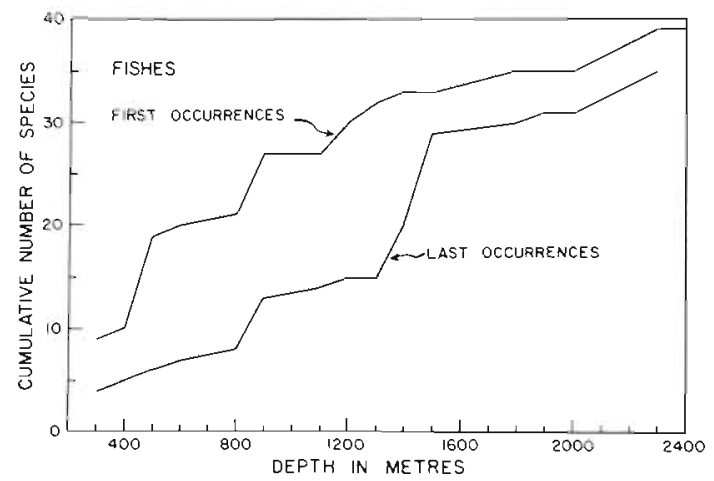

Fig. 3. Cumulative number of fish species taken on the Newfoundland continental slope as depth is increased by $100 \mathrm{~m}$ increments

occurrences (i.e. species encountered for the first time as depth of sampling is increased) and the lower curve is for last occurrences (i.e. species encountered for the last time as depth of sampling is increased). The curve of first occurrences approaches an asymptote rather smoothly in comparison to the stepped recruitment curves shown in Haedrich et al. (1980: p. 168, Fig. 3), another indication that zonation is weak. There is a moderate step in the curve at about $900 \mathrm{~m}$ which is matched by a similar step in last occurrences. The abrupt increase in the number of last occurrences at about $1500 \mathrm{~m}$ is not matched in the curve of first occurrences.

The potential boundaries suggested by the patterns in the recruitment curves were examined by calculating PS between the regions involved. PS measured across the $900 \mathrm{~m}$ level was $47 \%$. Across the $1500 \mathrm{~m}$ level PS was $12 \%$, and it is only here that a case for a faunal boundary can be made. However, this situation results only from species dropping out, not from encountering new ones (Fig. 3). The data thus do not suggest any pronounced pattern of zonation. Nonetheless, faunal composition in the shallow regions is quite different from that of the deeper sections. In order to quantify these differences, we divide the stations into 2 groups: those shallower than $1500 \mathrm{~m}$ and those deeper.

Table 3 shows how overall community parameters vary between shallow and deep sections. Abundance and biomass estimates both decline, with markedly lower catch rates on the lower slope. Fewer species occur deeper. As measured by $\mathrm{H}$, diversity is the same
Table 3. Community parameters and catch rates for fish assemblages at shallow $(<1500 \mathrm{~m})$ and deep $(>1500 \mathrm{~m})$ continental slope depths off Newfoundland

\begin{tabular}{|c|c|c|}
\hline & $\begin{array}{c}\text { Shallow } \\
(200-1475 \mathrm{~m})\end{array}$ & $\begin{array}{c}\text { Deep } \\
(1712-2335 \mathrm{~m})\end{array}$ \\
\hline No. of species & 33 & 10 \\
\hline Diversity, $\mathrm{H}$ & 1.5 & 1.5 \\
\hline Evenness, J & 0.4 & 0.7 \\
\hline No. of specimens & 4109 & 121 \\
\hline No. of stations & 26 & 6 \\
\hline Duration of trawls (h) & 9.0 & 2.7 \\
\hline Specimens $\mathrm{h}^{-1}$ & 455.7 & 45.0 \\
\hline $\mathrm{Kg} \mathrm{h}^{-1}$ & 93.1 & 19.7 \\
\hline
\end{tabular}

at both depths, but evenness $J$ is somewhat greater in the deep region.

No one species is dominant over the whole sampling range, but Antimora rostrata is among the top 6 both shallow and deep (Table 4). By far the most important family in terms of both number and biomass is the macrourids (Macrourus berglax, Coryphaenoides

Table 4 . The 6 most abundant demersal fish species at shallow $(<1500 \mathrm{~m})$ and deep $(>1500 \mathrm{~m})$ continental slope depths off Newfoundland. Values are percentages of total number and of total biomass

\begin{tabular}{|lcc|}
\hline Species & Number (\%) & Biomass (\%) \\
\hline Shallow (200-1475 m) & & \\
Coryphaenoides rupestris & 59.1 & 26.5 \\
Macrourus berglax & 14.2 & 21.4 \\
Antimora rostrata & 8.2 & 12.8 \\
Nezumia bairdii & 5.3 & 3.6 \\
Sebastes sp. & 4.1 & 3.8 \\
Synaphobranchus kaupi & 3.4 & 2.0 \\
Deep (1712-2335 m) & & \\
Antimora rostrata & 53.3 & 74.1 \\
Nematonurus armatus & 12.5 & 6.1 \\
Chalinura brevibarbis & 10.0 & 6.5 \\
Lionurus carapinus & 10.0 & 0.9 \\
Alepocephalus sp. & 6.7 & 9.4 \\
Synaphobranchus kaupi & 3.3 & 1.6 \\
& & \\
\hline
\end{tabular}

rupestris, Nezumia bairdii, and Nematonurus armatrus), which is the most numerous group in all regions less than $1600 \mathrm{~m}$, and comprises the dominant biomass in most regions shallower than $1200 \mathrm{~m}$. In those areas where macrourids do not dominate, they are second only to the morid $A$. rostrata. Below $1200 \mathrm{~m}$, this species comprises the dominant biomass, and is the most abundant species below $1600 \mathrm{~m}$.

Each species has a unique vertical depth range (Fig. 4). Those of Synaphobranchus kaupi, Antimora rostrata, and Alepocephalus $s p$. are quite wide, while 


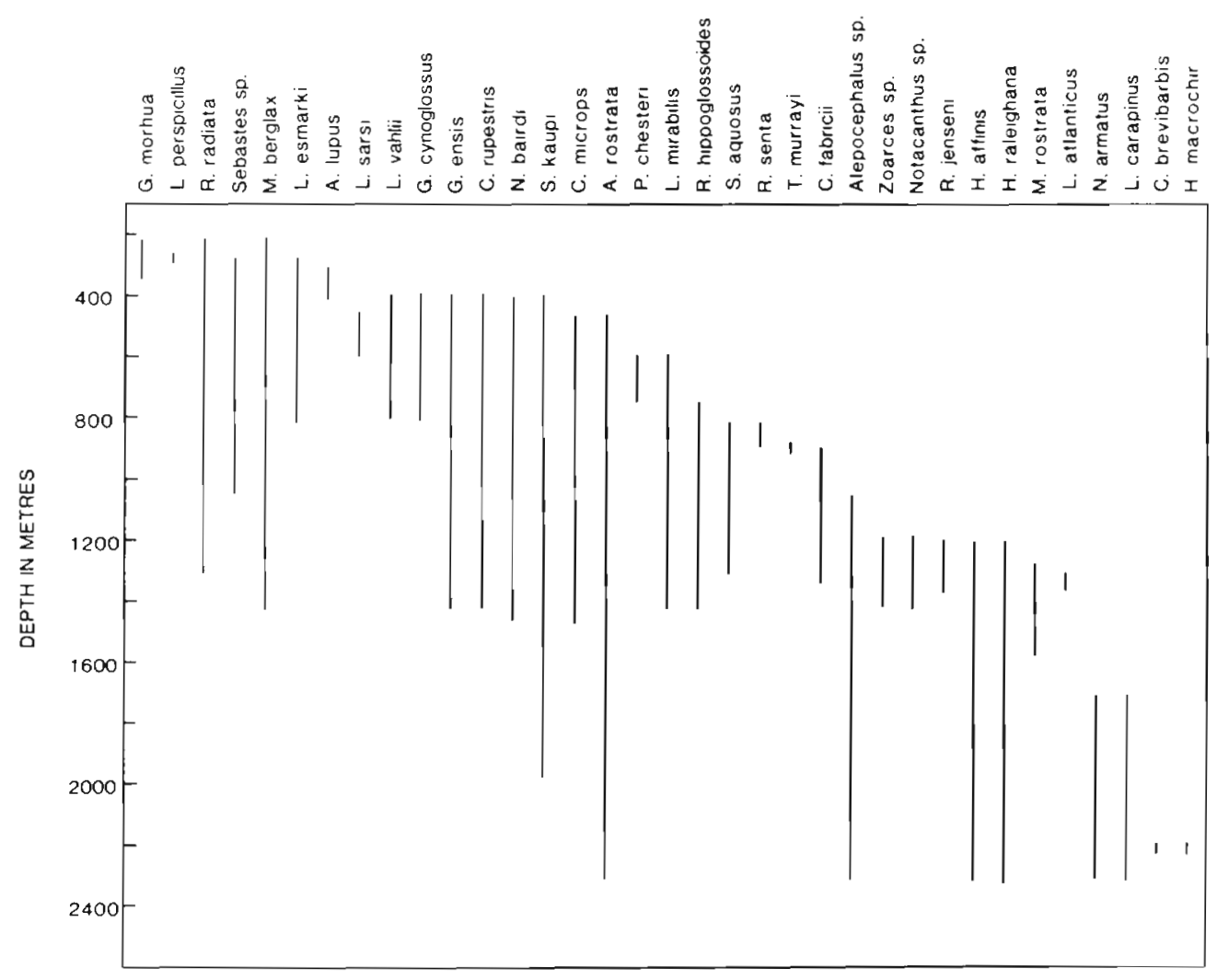

Fig. 4. Vertical depth ranges for fish species taken in bottom trawls on the Newfoundland continental slope

other species such as Anarhichas lupus, Phycis chesteri, Centroscyllium fabricii, and Lycenchelys sarsi occurred in very narrow zones.

The regression of mean weight per individual for all taxa combined versus depth was not significantly different from zero. Of individual species, only Antimora rostrata (Fig. 5) and Coryphaenoides rupestris (Fig. 6) showed a significant bigger-deeper relation.

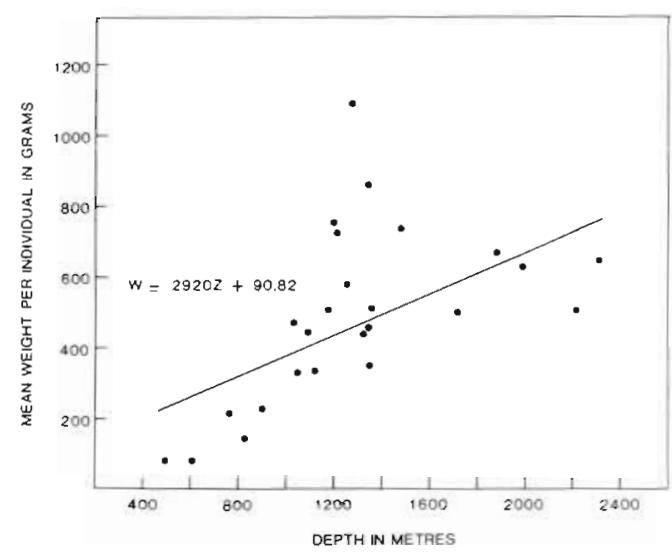

Fig. 5. Antimora rostrata. Size-depth relation. The regression is significant: $\mathrm{r}=0.52, \mathrm{p}<.007 . \mathrm{N}=402$; only the mean value for each station is plotted

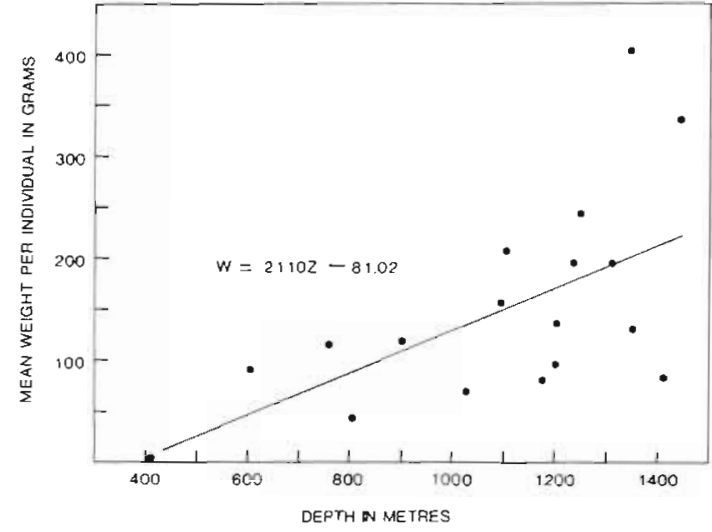

Fig. 6. Coryphaenoides rupestris. Size-depth relation. The regression is significant: $\mathrm{r}=0.63, \mathrm{p}<.008 . \mathrm{N}=2424$; only the mean value for each station is plotted

\section{DISCUSSION}

Deep demersal fish faunas seem to follow the general rule of decline in species number with increasing latitude. Seventy-two species were taken off New England between 200 and $2400 \mathrm{~m}$ (Haedrich et al. 1980), 39 off Newfoundland, and 39 between Greenland and Iceland (Haedrich \& Krefft 1978). Off northwest Africa, 
between $8^{\circ}$ and $27^{\circ} \mathrm{N}$, about 148 species were taken over a comparable depth range (Merrett \& Marshall 1980). In the Pacific at about $45^{\circ} \mathrm{N}$, Pearcy et al. (1982) recorded 61 species on the continental slope. Ohta (1983) reports 79 fish species between 200 and $2400 \mathrm{~m}$ in Suruga Bay, Japan (ca $35^{\circ} \mathrm{N}$ ). Different gear and varying numbers of stations in these studies mean that results may not be absolutely comparable, but the trend is clear. Sulak (1984), using gear identical to ours but with many more stations, took 74 fish species at slope depths in the Middle Atlantic Bight (ca $37^{\circ} \mathrm{N}$ ) and 85 in the Bahamas ( $\mathrm{Ca} 24^{\circ} \mathrm{N}$ ). For these data, the regression of number of fish species on latitude, $\mathrm{S}=$ $153-2.03 \mathrm{~L}$, is significant $(\mathrm{r}=.85, \mathrm{p}<.01, \mathrm{n}=8$ )

Haedrich et al. (1980) found that macrourids such as Nezumia bairdii and Coryphaenoides rupestris are quite important on the New England continental slope from about $653 \mathrm{~m}$ to $1290 \mathrm{~m}$, and Haedrich \& Krefft (1978) found Macrourus berglax and C. rupestris dominated the $500 \mathrm{~m}$ to $1500 \mathrm{~m}$ range in the Denmark Strait. Both of these findings are consistent with ours, as is the dominance of Antimora rostrata from about $1500 \mathrm{~m}$ to the base of the slope. Pearcy et al. (1982) also found a macrourid (Coryphaenoides acrolepis) and a morid (Antimora microlepis) dominated the Northeastern Pacific slope.

Coryphaenoides rupestris appears to be most abundant in the canyon environment. All 11 stations made in Carson Canyon took this species, with an average catch rate of 557 individuals and $48.9 \mathrm{~kg} \mathrm{~h}^{-1}$. Of 21 stations outside the Canyon, only 9 took $C$. rupestris, and the average catch rate at these was 116 individuals and $13.9 \mathrm{~kg} \mathrm{~h}^{-1}$. We have re-examined the data of Haedrich et al. (1980), and find that there, off New England, canyon stations accounted for $95 \%$ of the $C$. rupestris taken. Nine stations in canyons took this species (25 individuals, $4.8 \mathrm{~kg} \mathrm{~h}^{-1}$ ) but only 1 station outside canyons did ( 7 individuals, $1.5 \mathrm{~kg} \mathrm{~h}^{-1}$ ). Hecker (pers. comm.; see 1983) found that $C$. rupestris off New York occurred only in canyons, and was never encountered on the open slope.

Longfin hake Phycis chesteri and the eel Synaphobranchus kaupi were dominant on the upper slope off New England (Haedrich et al. 1980). Both species were much less abundant off Newfoundland, and the Grand Banks region would seem to be the northern limit of the distribution for these fishes (Methven \& McKelvie 1986). Several species found on the Newfoundland continental slope are new records for the area. Chalinura brevibarbis, Halosauropsis macrochir, Lionurus carapinus, and Lycodes perspicillus have not been described previously from Canadian waters (Steigerwald \& McAllister 1982). None of these were particularly abundant, and $H$. macrochir and L. perspicillus were represented only by single specimens.
The weak vertical zonation in our study is similar to the findings of Merrett \& Marshall (1980) on the Northwest African Slope. They attributed this situation to the high productivity of that area. High production is also characteristic of the Newfoundland slope (KoblentzMishke et al. 1970). However, a modest degree of zonation was found on the Oregon slope (Pearcy et al. 1982), which is also highly productive. The similarity of these areas makes it difficult to evaluate the influence of productivity on zonation, and only the examination of a very unproductive area could properly address the question. Sulak (1984) found little evidence for zonation among deep benthic fishes of the relatively oligotrophic waters of the Bahamas.

Based on the ideas of Menzies et al. (1973), several zones should be encompassed within our sampling range. Those authors define a Shelf Faunal Province (about 5 to $250 \mathrm{~m}$ ), an Archibenthal Zone of Transition (about 445 to $900 \mathrm{~m}$ ), and an Upper Abyssal Zone (about 940 to $2635 \mathrm{~m}$ ), as well as others that go well below our sampling range. Haedrich et al. (1980) define a broader archibenthal zone (300 to $1300 \mathrm{~m}$ ) and divide the slope into upper ( 300 to $700 \mathrm{~m}$ ) and lower (700 to $1300 \mathrm{~m}$ ) zones. Thus, although our sampling range was more restricted than those of Haedrich et al. (1980) and Pearcy et al. (1982), the absence of the expected distinct zones within our range indicates that zonation of fish assemblages is not present off Newfoundland. The failure to find pronounced zones here undermines the belief that regions containing uniform and predictable assemblages of species continuously rim the ocean basins (Menzies et al. 1973). Breaks in supposedly continuous faunal zones have been found in shallower depths (Dauer \& Simon 1975) and on the continental slope (Markle \& Musick 1974, Cutler 1975).

The 'bigger-deeper' phenomenon (e.g. Polloni et al. 1979, Wenner \& Musick 1977) has been reported for several of the species we found in large numbers. Antimora rostrata, Synaphobranchus kaupi, Nematonurus armatus, and Nezumia bairdii are all species which Polloni et al. (1979) found to be bigger-deeper. Only A. rostrata and Coryphaenoides rupestris showed a significant bigger-deeper relation in our Newfoundland study.

The bigger-deeper relation observed in Antimora rostrata and Coryphaenoides rupestris may be related to a number of factors. Podrazhanskaya (1971) found the shallow waters of the North Atlantic slope to be the major area of development for C. rupestris young, and Wenner \& Musick (1977) suggested $A$, rostrata may also mature in this area. The presence of immature individuals in the shallower samples could create the appearance of a bigger-deeper relation where there was no such phenomenon. Larger individuals would 
be sampled at all depths whereas immatures would be seen only in shallow samples, creating the appearance of a bigger-deeper relation where one did not, in fact, exist. Selective net avoidance by larger fishes would further enhance this effect (Pearcy et al. 1982), a factor that could also have contributed to the bigger-deeper relation found by Polloni et al. (1979) and others.

The absence of a general bigger-deeper relation on the Newfoundland slope supports the possibility that the relation is not merely an artifact of selective net avoidance. The equipment used by Polloni et al. (1979) was identical to that used in our sampling, yet their study found fishes (all taxa combined) to be biggerdeeper while ours did not. Were net avoidance the only factor involved, we would also have found a biggerdeeper relation for fishes in general. The biggerdeeper relation may in fact be a geographically limited phenomenon. Sulak (1984) found it to be characteristic of fishes in the Middle Atlantic Bight, a situation he reported to be in sharp contrast to the Bahamas where the relation was absent.

Wenner \& Musick (1977) noted an absence of smaller specimens of Antimora rostrata in their study near Norfolk Canyon, U.S.A., and suggested that spawning occurred in the north. Two aspects of our data support this hypothesis. First, the standard lengths of their fishes, except in a few instances, were consistently over $20 \mathrm{~cm}$, and they noted a marked absence of small specimens. The Newfoundland samples contain numerous specimens between 10 and $20 \mathrm{~cm}$, particularly at shallow depths; this relates to the second point. Except for 1 specimen caught at $792 \mathrm{~m}$. Wenner \& Musick (1977) did not obtain specimens from any samples shallower than $1000 \mathrm{~m}$. A. rostrata frequently occurred in many of our samples between 500 and 1000 $\mathrm{m}$. The northwest North Atlantic can be considered a nursery area for Coryphaenoides rupestris, but parasitological evidence indicates that this population migrates a considerable distance to the Mid-Atlantic Ridge to spawn (Zubchenko 1985).

Andriashev (1954) defined primary species as those deep water fishes whose evolutionary radiation took place in the deep ocean, as opposed to secondary deep water fishes which evolved in shallow water and have been able to colonize deeper water secondarily of those groups represented in our sampling, the families Alepocephalidae, Chimaeridae, Macrouridae, Halosauridae, Moridae, Notacanthidae, and Synaphobranchidae are all primary, while all others are secondary.

The percentage of primary species increases steadily with depth (Fig. 7). The general rate of increase in primary species, as expressed by the slope of the relation, is the same ( $m=4.2$ and 4.3 respectively, $z$ in $\mathrm{km}$ ) as that reported by Haedrich \& Krefft (1978) for the Irminger Sea and steeper than the slope $(\mathrm{m}=2.8$ ) calculated from the original data of Haedrich et al. (1980) off New England. Haedrich \& Krefft (1978) suggested this situation might indicate an ongoing invasion of the deep sea from shallow waters at high latitudes. Working with invertebrate faunas that have more complete fossil histories than fishes, Zinsmeister \& Feldmann (1984) and Buzas \& Culver (1984) have recently supported such a view. In the Isopoda, Wilson

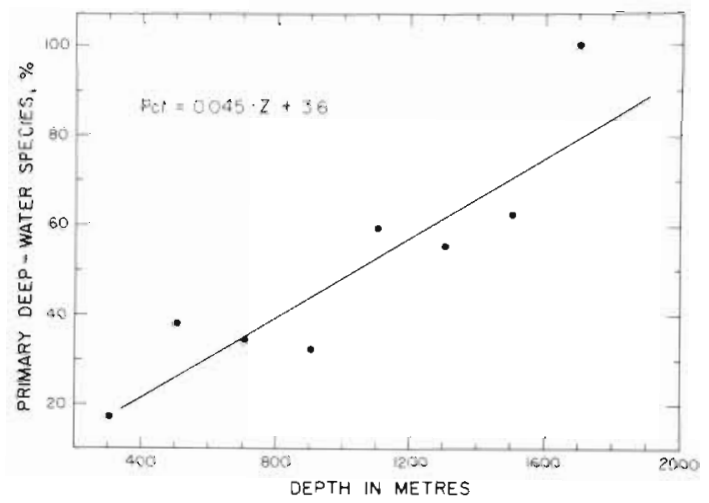

Fig. 7. Percentage of primary deep-water fish species in the fauna as a function of depth, by $200 \mathrm{~m}$ increments, on the Newfoundland continental slope. The regression is significant: $\mathrm{r}=0.86, \mathrm{p}<.01$

(1980) points out an interesting contrast between the Munnidae, which appear to be entering the deep sea from both poles, and the Pleurogoniidae, which entered the deep sea from the Antarctic, diversified in deep water, and re-emerged in the Arctic

A review by Somero et al. (1983) on the biochemical adaptations of deep-sea animals offers some insight concerning colonization of the deep sea by shallowwater forms from polar regions. They point out that deep-sea species possess enzymes and other cellular adaptations to high pressure and low temperature which enable them to function at great depths. It is possible that the shallow-water fishes present in the Denmark Strait area have physiological adaptations to the cold environment that have made invasion of the cold, but high pressure environment possible. Patton (1975) found that the phospholipid composition of the deep-sea Antimora rostrata and the cold-adapted Antarctic shallow-water fish Pagothenia borchgrevinki were not significantly different. Adaptations such as a reduction in phospholipid fatty acid saturation not only enable fishes to invade a cold environment, but may also allow penetration into deep waters. This would mean the shallow-water, cold-adapted northern species might be more able to invade deep waters than species living in more temperate waters, and far-northern deep-water assemblages would thus tend to be more a mixture of primary and secondary species 
Acknowledgements. Sally Babie and S. H. Lee have aided us in laboratory processing. We thank D. S. McKelvie, K. A. Houston, J. M. Richard, and J. A. Hutchings for their help at sea. These people and also J. McGlade have provided useful comments on the manuscript. The work was supported by grant A-7230 from the Natural Sciences and Engineering Research Council. Contribution no. 64 from the Newfoundland Institute for Cold Ocean Science.

\section{LITERATURE CITED}

Andriashev, A. P. (1954). Primary deep-water and secondary deep-water fishes and their importance in a zoogeographical analysis. Notes on questions of general ichthyology. Academy of Sciences of the USSR, Ichthyological Commission, p. 58-64

Bullis, H. R. Jr., Cummins, R., Jr. (1963). Another look at the royal red shrimp resource. Proc. Gulf. Caribb. Fish. Inst. 15 th ann. Sess., p. 9-12

Buzas, M. A., Culver, S. J. (1984). Species duration and evolution: benthic foraminifera on the Atlantic continental margin of North America. Science 224: 829-830

Carney, R. S., Haedrich, R. L., Rowe, G. T (1983). Zonation of fauna in the deep sea. In: Rowe, G. $T$ (ed.) Deep-sea biology, Vol. 8, The sea. John Wiley and Sons, New York, p. 371-398

Cohen, D. M., Pawson, D. L. (1977). Observations from the DSRV Alvin on populations of benthic fishes and selected larger invertebrates in and near DWD-106. Baseline report on Environmental Conditions in Deep-water Dumpsite 106. U.S. Department of Commerce, NOAA, Dumpsite evaluation report 77-1,2, Biological characteristics

Cutler, E. B. (1975). Zoogeographical barrier on the continental slope off Cape Lookout, North Carolina. Deep Sea Res. 22: 893-901

Dauer, D. M., Simon, J. L. (1975). Lateral or along-shore distribution of the polychaetous annelids of an intertidal, sandy habitat. Mar. Biol. 31: 363-370

Day, D. S., Pearcy, W. G. (1968). Species associations of benthic fishes on the continental shelf and slope off Oregon. J. Fish Res. Bd Can. 25: 2665-2675

Gardiner, F. P., Haedrich, R. L. (1978). Zonation in the deep benthic megafauna; application of a general test. Oecologica (Berl.) 31: 311-317

Graham, M. S., Haedrich, R. L., Fletcher, G. L. (1985) Hematology of three deep sea fishes: a reflection of low metabolic rates. Comp. Biochem. Physiol 80A(1): 79-84

Haedrich, R. L., Rowe, G. T., Polloni, P. T. (1975). Zonation and faunal composition of epibenthic populations on the continental slope south of New England. J. mar. Res. 33: 191-212

Haedrich, R. L., Rowe, G. T., Polloni, P. T. (1980). The megabenthic fauna in the deep sea south of New England, U.S.A. Mar. Biol. 57: 165-179

Haedrich, R. L., Krefft, G. (1978). Distribution of bottom fishes in the Denmark Strait and Irminger Sea. Deep Sea Res. 25: $705-720$

Hecker, B. (1983). Comparison of epifaunal assemblages in two east coast submarine canyons. EOS Trans. Am. geophys. Un. 64(52): 1060

Koblentz-Mishke, O. J, Volkovinsky, V. V., Kabanova, J. G. (1970). Plankton primary production of the world ocean. Symposium on Scientific Exploration of the South Pacific. National Academy of Sciences, Washington, D.C. p. 183-193
Markle, D. F., Musick, J. A. (1974). Benthic-slope fishes found at $900 \mathrm{~m}$ depth along a transect in the Western North Atlantic Ocean. Mar. Biol. 26: 225-233

Menzies, R. J., George, R. Y., Rowe, G. T. (1973). Abyssal environment and ecology of the world oceans. John Wiley and Sons, New York

Merrett, N. R., Marshall, N. B. (1980). Observations on the ecology of deep-sea bottom-living fishes collected off northwest Africa $08^{\circ}-27^{\circ} \mathrm{N}$. Prog. Oceanogr 9: 185-244

Methven, D. A., McKelvie, D. S. (1986). Distribution of Phycis chesteri on the Grand Bank and Labrador Shelf. Copeia (in press)

Ohta, S. (1983). Photographic census of large-sized benthic organisms in the bathyal zone of Suruga Bay, central Japan. Bull. Ocean Res. Inst., Univ. Tokyo 15: 1-244

Patton, J. S. (1975). The effect of pressure and temperature on phospholipid and triglyceride fatty acids of white fish muscle, a comparison of deepwater and surface marine species. Comp. Biochem. Physiol. 59B: 207-212

Pearcy, W. G., Stein, D. L., Carney, R. S. (1982). The deep-sea benthic fish fauna of the Northeastern Pacific Ocean on Cascadia and Tufts abyssal plains and adjoining continental slopes. Biol. Oceanogr. 1: 375-428

Podrazhanskaya, S. G. (1971). Feeding and migrations of the roundnose grenadier, Macrourus rupestris in the northwesi Atlantic and Iceland waters. Int. Comm. for the North Atlantic Fisheries (ICNAF), Redbook. Part 3: 115-123

Polloni, P. T., Haedrich, R. L., Rowe, G. T., Clifford, C. H (1979). The size-depth relationship in deep ocean animals. Int. Revue ges. Hydrobiol. 64: 39-46

Ray, A. A. (ed.) (1982). SAS users guide, basics. 1982 ed. SAS Institute, North Carolina

Shannon, C. E., Weaver, W. (1963). The mathematical theory of communication. Univ, of Illinois Press, Urbana

Somero, G. N., Siebenaller, J. F., Hochachka, P. W. (1983) Physiological adaptations of deep-sea animals. In: Rowe, G. T. (ed.) Deep-sea biology, Vol. 8, The Sea. John Wiley and Sons, New York, p. 261-330

Steigerwald, M. B., McAllister, D. E. (1982). List of the Canadian marine fish species in the National Museum of Natural Sciences, National Museums of Canada. Sy]logeus 41: 1-30

Sulak, K. J. (1984). A comparative ecological analysis of temperate and tropical demersal deep-sea fish faunas in the western North Atlantic. Ph. D. thesis, Univ. of Miami, p. 1-211

Wenner, C. A., Musick, J. A. (1977). Biology of the morid fish Antimora rostrata in the western North Atlantic. J. Fish. Res. Bd Can. 34: 2362-2368

Whittaker, R. H., Fairbanks, C. W. (1958). A study of plankton copepod communities in the Columbia Basin, southeastern Washington. Ecology 39: 46-65

Wilson, G. D. (1980). New insights into the colonization of the deep sea: systematics and zoogeography of the Munnidae and the Pleurogoniidae comb. nov. (Isopoda; Janiroidea). J. nat. Hist. 14: 215-236

Zinsmeister, W. J., Feldmann, R. M. (1984). Cenozoic high latitude heterochroneity of southern hemisphere marine faunas. Science 224: 281-283

Zubchenko, A. V. (1985). Use of parasitological data in studies of the local groupings of rock grenadier, Coryphaenoides rupestris Gunther. In: Hargis, W. J., Jr. (ed.) Parasitology and pathology of marine organisms of the world ocean. NOAA Technical Report NMFS (National Marine Fisheries Service) 25: 19-23 